\title{
METHOD FOR IMPROVING THE QUALITY OF MIDDLE-HEAVY SHALE OIL AND FOR INCREASING COMMODITY OUTPUT AT THERMAL PROCESSING OF FUELS IN THE SOLID HEAT CARRIER UNIT
}

\author{
K. KAIDALOV ${ }^{(\mathrm{a}, \mathrm{b})^{*}}, \mathrm{~A}^{\mathrm{b}} \mathrm{KAIDALOV}^{(\mathrm{b})}$ A. ELENURM $^{(\mathrm{c})}$, \\ B. KINDORKIN $^{(b)}$, S. VERESHCHAKA ${ }^{(b)}$ \\ (a) Department of Oil Shale Technology \\ Tallinn University of Technology \\ 5 Ehitajate Rd., 19086 Tallinn, Estonia \\ (b) Oil Plant of Narva PP \\ 59 Elektrijaama Rd., 21004 Narva, Estonia \\ (c) Chemical Engineering Department \\ Tallinn University of Technology \\ 5 Ehitajate Rd., 19086 Tallinn, Estonia
}

\begin{abstract}
The offered method for improving the quality of middle-heavy shale oil proposes changes in the condensation system of the solid heat carrier unit. Substitution of parallel flow of heavy shale oil and vapor phase in the air cooler-condenser for their counter-current flow accelerates evacuation of vapor-gas mixture from the high-temperature zone, increases oil yield and decreases the rate of oil bodying.
\end{abstract}

\section{Introduction}

Shale oil products produced at Oil Plant of Narva Power Plant (Oil Plant NPP) are widely used as liquid fuel for furnaces and boilers, and also as constituents for preparing different combustibles, especially for river and sea vessels. The better the quality of middle-heavy shale oil fractions and the less their sulfur content, the better the characteristics of fuels made on their basis. During the last years on the oil export market there has been keen interest in the shale oil fraction characterized by density as low as $1000 \mathrm{~kg} / \mathrm{m}^{3}$, viscosity $\gamma_{80} \leq 30 \mathrm{cSt}$, and flash point in closed crucible $\geq 55^{\circ} \mathrm{C}-\mathrm{a}$

\footnotetext{
*Corresponding author: e-mail address kirill.kaidalov@nj.energia.ee
} 
constituent of bunker fuel for fleet. This fraction is prepared at Oil Plant by compounding the middle-heavy shale oil with gas turbine fuel (GTF) fraction.

Shale oil fractions obtained at oil shale retorting at Oil Plant NPP are used as components for preparing commodity outputs according to Oil Plant Standard EE10579981 [1].

\section{Technological process of thermal processing in the solid heat carrier unit - TSK Oil Plant NPP}

The technological process includes three fundamental operations (Fig. 1):

1. Drying and preheating of fine-grained oil shale in the drier in the atmosphere of hot stack gas from the heat regeneration furnace.

2. Thermal low-temperature carbonization of dry shale in a continous process of mixing with hot heat carrier in the rotary drum reactor. As heat carrier the ash of spent oil shale is used.

3. Combustion of the mixture of semi-coke and heat carrier in the heat regeneration furnace for heating up the ash as heat carrier for the following cycle.

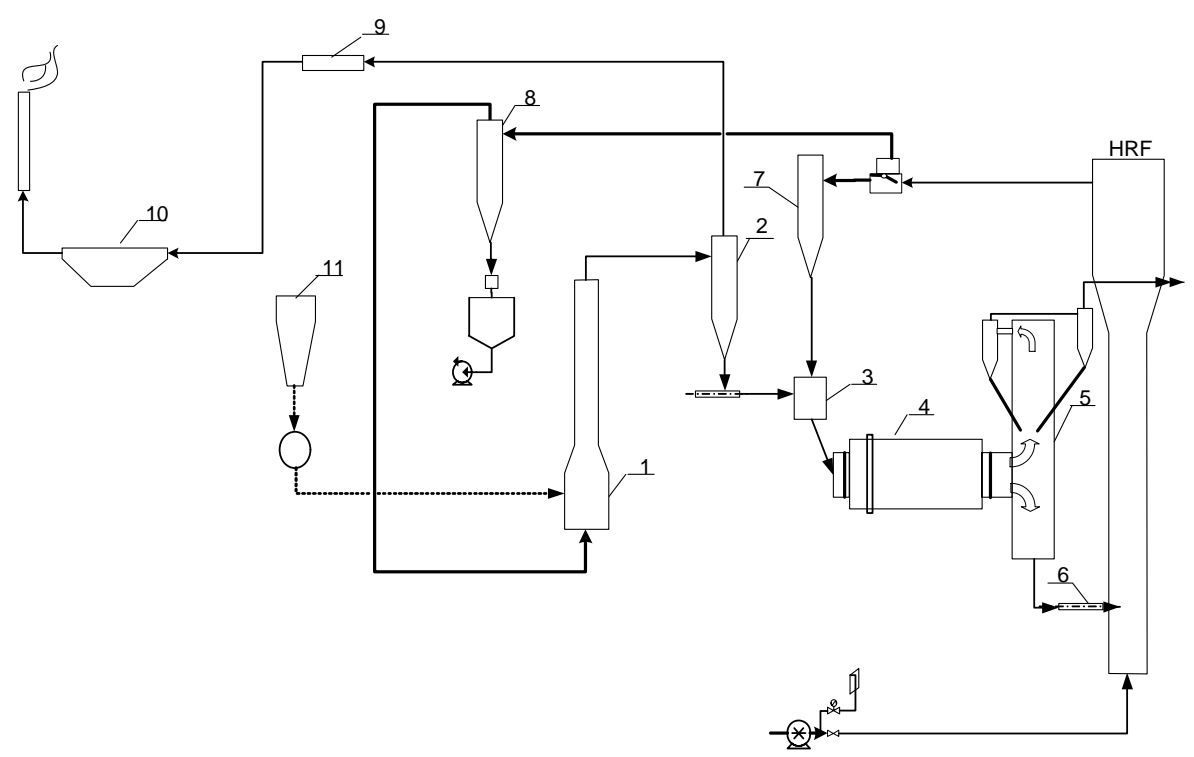

Fig. 1. Schematic diagram of thermal processing in the solid heat carrier unit - TSK Oil Plant NPP.

1 -drier, 2 -dry oil shale cyclone, 3-mixer, 4-rotary drum reactor, 5-dust separator, 6-screw-conveyor, 7 - heat carrier cyclon, 8-ash cyclone, 9-gaswasher, 10 - electrical precipitator, 11 - oil shale storage tank, HRF - heat regeneration furnace. 
Oil shale crushed to the size $<25 \mathrm{~mm}$ is fed into the drier (1) where drying and preheating of oil shale are realized in the flow of hot (700$750{ }^{\circ} \mathrm{C}$ ) stack gas. Dry preheated to $150-160{ }^{\circ} \mathrm{C}$ oil shale is separated from stack gas in the dry oil shale cyclone (2) and fed to the mixer (3), where it is mixed with an 1.9-2.1-fold quantity of hot solid heat carrier (ash of spent oil shale). The mixture is fed into the rotary drum reactor (4) where in the course of 15-20 min over $80 \%$ of organic substance of oil shale is converted into liquid and gaseous products [2-4].

Very small size and large surface areas of oil shale and heat carrier particles ensure their close contact in the mixing process in the reactor and a high rate of oil shale feed resulting in rapid heating of the reactor.

The mixture of spent oil shale and heat carrier from the reactor is separated from the vapor-gas mixture in the dust separator (5) and fed by the screw-conveyor (6) to the heat regeneration furnace (HFR).

Calorific value $1185-1423 \mathrm{~kJ} / \mathrm{kg}(283-340 \mathrm{kcal} / \mathrm{kg})$ of the spent oil shale and heat carrier mixture whose temperature is in the range $430-450{ }^{\circ} \mathrm{C}$ is sufficient to cover heat consumption of thermal processing.

Ash residue from the heat regeneration furnace is transported together with stack gas through the system of cyclons. In the heat carrier cyclon (7) relatively coarse granulometric fraction of ash is separated from the flow of stack gas and directed through the mixer (3) together with oil shale back to the reactor. Exess ash is removed from stack gas in ash cyclones (8).

The heat of stack gas and exess ash can be utilized in the waste heat incinerator. Stack gas is cleaned in the gas-washer (9) and the electrical precipitator (10) before outlet to the open air.

Vapor-gas mixture (VGM) produced in the reactor is sent for condensation through the dust separator (5), where by means of connected cyclones volatile products are separated from the mixture of spent oil shale and heat carrier.

\section{Condensation system of the solid heat carrier unit - TSK Oil Plant NPP}

Volatile products of thermal processing leave the dust separator at 465$490{ }^{\circ} \mathrm{C}$ and enter the scrubber tower (1) of the condensation system (Fig. 2) where residual dust is removed by washing with circulating condensed heavy shale oil.

Thereafter VGM is directed through the air cooler-condenser (2), where the main condensation of heavy shale oil takes place - separation of liquid and vapour phases in the counter-current process.

Heavy shale oil at the temperature $320^{\circ} \mathrm{C}$ is collected in the gas collector. The condensed heavy shale oil is directed to the boiling pulp of the rectifying column (3), where it is mixed with the medium fraction of shale oil, separated in the column. Characteristics of oil fractions are given in Table 1. 


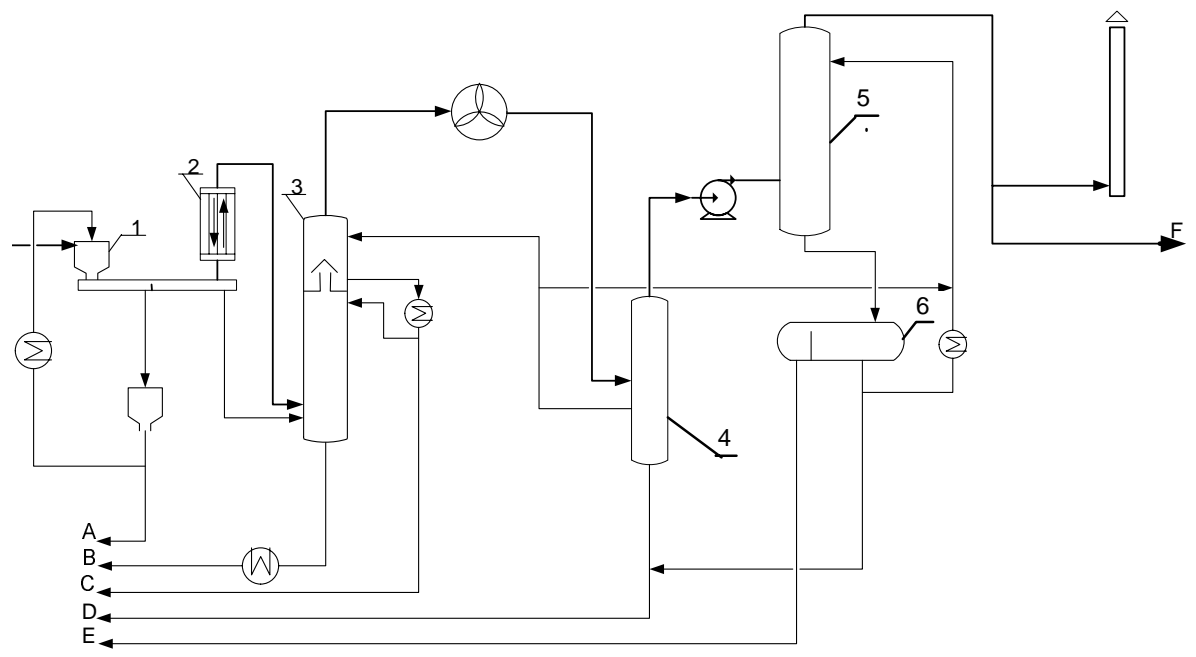

Fig. 2. Condensation system of the solid heat carrier unit - TSK Oil Plant NPP.

A - Heavy shale oil; B - Middle-heavy shale oil; C-Gas turbine fuel (GTF); D - Gasoline; E - Phenolic water; F - Retorting gas.

1 - crubber tower, 2 - air cooler-condenser, 3 - rectification column, 4 - separator, 5 - scrubber, 6 - intermediate receiver for phenolic water and gasoline.

Table 1. Distribution and characterization of oil fractions produced in the solid heat carrier unit

\begin{tabular}{|l|c|c|c|}
\hline \multicolumn{1}{|c|}{ Characteristics } & Middle-heavy oil & GTF & Gasoline \\
\hline Production quantities, total oil & 70 & 10 & 20 \\
$\quad$ basis, \% & 35 middle and 35 heavy & & \\
Viscosity, cSt & $\leq 28_{80}$ & $\leq 3.0_{50}$ & - \\
Density at $15{ }^{\circ} \mathrm{C}, \mathrm{kg} / \mathrm{m}^{3}$ & $\leq 1045$ & $\leq 920$ & $\leq 820$ \\
Flash point in open crusible, ${ }^{\circ} \mathrm{C}$ & $\geq 120$ & $\geq 55$ & $\leq-10$ \\
Ash content, \% & $\leq 0.15$ & $\leq 0.015$ & traces \\
Water content, \% & $\max \leq 0.3$ & $\max \leq 0.3$ & $\max \leq 0.3$ \\
Sulfur content, $\%$ & $0.4-0.7$ & $0.5-1.0$ & $0.9-1.4$ \\
\hline
\end{tabular}

In order to get middle-heavy shale oil in accordance with Oil Plant Standard EE10579981, the quantity of heavy shale oil in the mixture is limited (50\%). It is necessary to add GTF fraction also for reducing the viscosity of middle-heavy shale oil.

Consequently, for preparation of the commodity output - liquid fuel as required - it is necessary either to increase the yield of GTF, which is complicated enough, or to decrease density and viscosity of middle-heavy shale oil fraction of produced shale oil. 
Main factors increasing density and viscosity of heavy shale oil fraction separated in the air cooler-condenser and a feasible method for decreasing their values

In the air cooler-condenser during the counter-current process effective mass exchange between flowing downwards condensed heavy shale oil and moving upwards vapour phase takes place.

In the case of counter-current moving, overheating of condensed heavy shale oil at the temperature $340{ }^{\circ} \mathrm{C}$ takes place, which leads to its intensive polymerization in the piping of the air cooler-condenser. Primary decomposition products of VGM are thermally unstable and inclined to subsequent thermal bodying.

It is essential to note that the light fractions, which in the condensation process are captured by heavy shale oil, also take part in bodying reactions (polycondensation and polymerization) being at the same time interversibly bound.

From this follows the principal rule of shale oil treatment: acceleration of evacuation of VGM from the high-temperature zone has a positive effect on shale oil yield and decreases the rate of bodying $[5,6]$.

To decrease density and viscosity of heavy and middle-heavy shale oil and also the yield of the GTF fraction, the residence time of heavy shale oil and VGM in the high-temperature zone is to be reduced converting the counter-current flow of VGM and heavy oil condensate to a parallel process.

The residence time of the liquid phase of heavy shale oil in the air coolercondenser was calculated according to the procedure treating the flowing of film-liquid and VGM for both processes. Initial data are given in Table 2.

It was determined that the residence time of the heavy shale oil fraction in the air cooler-condenser in the parallel process conditions becomes about 100 times shorter compared with the counter-current conditions.

Table 2. Characterization of VGM flowing through the air cooler-condenser

\begin{tabular}{|l|c|c|}
\hline & At entering & At outlet \\
\hline Quantity, kg/h & 28,000 & 21,296 \\
Molecular mass & 53 & 50 \\
Pressure, $\mathrm{Pa}$ & 91,332 & 91,082 \\
Speed of VGM, m/s & 4.96 & 3.02 \\
\hline
\end{tabular}

\section{Calculation of residence time of heavy shale oil fraction in the air cooler-condenser at the existing counter-current process and the proposed parallel one [7]}

1. Tension of frictional force of VGM in the pipe element of the air cooler-condenser at the counter-current flow: 


$$
\tau_{\mathrm{M}}=\frac{\left(P_{\mathrm{s}}-P_{\mathrm{v}}\right) \cdot d}{4 \cdot L}=\frac{(91332-91082) \cdot 57 \cdot 10^{-3}}{4 \cdot 6}=0.59375 \mathrm{~Pa},
$$

where

$P_{\mathrm{s}}$ - pressure of VGM at entering the air cooler-condenser, $\mathrm{Pa}$

$P_{\mathrm{v}}$ - pressure of VGM at outlet from the air cooler-condenser, $\mathrm{Pa}$

$d$ - pipe diameter, $\mathrm{m}$

$L$ - pipe lenght, $\mathrm{m}$

2. Mean thickness of the heavy shale oil film in the pipe:

$$
\delta=\sqrt[3]{3 \cdot \mu_{\mathrm{ho}} \cdot V_{1} / \rho_{h o} \cdot g}=\sqrt[3]{3 \cdot 0.001 \cdot 1.522 \cdot 10^{-5} / 1055 \cdot 9.8}=1.64 \cdot 10^{-4} \mathrm{~m},
$$

where

$$
\mu_{\mathrm{ho}}-\text { viscosity of heavy shale oil at } 320-340{ }^{\circ} \mathrm{C}, \mathrm{Pa} \cdot \mathrm{s}
$$

$V_{1}-$ line density of wetting, $\mathrm{m}^{3} / \mathrm{m} \cdot \mathrm{s}$

$$
\rho_{\text {ho }}-\text { density of heavy shale oil at } 320-340{ }^{\circ} \mathrm{C}, \mathrm{kg} / \mathrm{m}^{3}
$$

3. Mean speed of the heavy shale oil film in the pipe of the air coolercondenser at the counter-current flow of VGM:

$$
\begin{aligned}
w_{\text {ho }} & =\frac{\rho_{\text {ho }} \cdot g \cdot \delta^{2} \cdot\left(1 / 3-\tau_{\mathrm{M}} / 2 \rho_{\mathrm{ho}} \cdot g \cdot \boldsymbol{\delta}\right)}{\mu_{\mathrm{ho}}} \\
& =\frac{1055 \cdot 9.8 \cdot\left(1.64 \cdot 10^{-4}\right)^{2} \cdot\left(1 / 3-0.59375 / 2 \cdot 1055 \cdot 9.8 \cdot 1.64 \cdot 10^{-4}\right)}{0.001} \\
& =0.044 \mathrm{~m} / \mathrm{s} .
\end{aligned}
$$

4. Line density of wetting:

$$
\begin{aligned}
& V_{1}=\delta \cdot w_{\mathrm{ho}}=\left(\rho_{\mathrm{ho}} \cdot g \cdot \delta^{3}\right) / 3 \mu_{\mathrm{ho}}=V_{\mathrm{ho}} / \pi \cdot d= \\
& =\left(2.724 \cdot 10^{-6}\right) / 3.14 \cdot 57 \cdot 10^{-3}=1.522 \cdot 10^{-5} \mathrm{~m}^{3} / \mathrm{m} \cdot \mathrm{s},
\end{aligned}
$$

where

$V_{\text {ho }}-$ volume of condensed heavy oil in tube in time, $\mathrm{m}^{3} / \mathrm{s}$.

5. Mean speed of the heavy shale oil film in the pipe of the air coolercondenser under gravitational force:

$$
w_{\mathrm{ho}}=V_{1} / \delta=1.522 \cdot 10^{-5} / 1.64 \cdot 10^{-4}=0.093 \mathrm{~m} / \mathrm{s} .
$$

6. Throughput time of the heavy shale oil film in the pipe of the air cooler-condenser under gravitational force:

$$
t_{\mathrm{t}}=L / w_{\mathrm{ho}}=6 / 0.093=64.5 \mathrm{~s} .
$$

7. Throughput time of the heavy shale oil film in the pipe of the air cooler-condenser at counter-current flow of VGM:

$$
t_{\mathrm{p}}=L / w_{\text {ho }}=6 / 0.044=136.4 \mathrm{~s} \text {. }
$$


8. Throughput time of the heavy shale oil film in the pipe of the air cooler-condenser at parallel flow process:

$$
t_{\mathrm{s}}=L / \mathrm{w}_{\mathrm{s}}=6 / 4.96=1.2 \mathrm{~s},
$$

where

$w_{\mathrm{s}}$ - mean speed of VGM at entering, $\mathrm{m} / \mathrm{s}$.

Calculation shows that in the case of parallel flow of condensing heavy shale oil and VGM, the residence time of heavy shale oil in the air coolercondenser decreases about 100 times, from $136 \mathrm{sec}$ to $1.2 \mathrm{sec}$.

According to the calculations given above we can propose that:

Converting the counter-current flow of VGM in the air cooler-condenser into the parallel flow process is a method for decreasing density and viscosity of the heavy shale oil fraction separated in the air cooler-condenser of the condensation system of thermal processing.

The parallel flow process in the air cooler-condenser enables to reduce the residence time of condensing heavy shale oil essentially, to decrease the temperature of condensing heavy shale oil from $320^{\circ} \mathrm{C}$ to $210^{\circ} \mathrm{C}$, to eliminate the active mass exchange between liquid and vapour phases, as a result of which the commodity output of shale oil increases by about $20 \%$.

The next step was a laboratory research of converting the counter-current flow of VGM in the air cooler-condenser into the parallel flow process.

The research was made by A. Elenurm, I. Rohtla and K. Kaidalov in the laboratory of Department of Chemical Engineering of Tallinn University of Technology.

The results of the experiment were very positive.

A potential alteration in the share of valuable GTF used for obtaining a blend with middle-heavy shale oil of above-mentioned parameters (density as low as $1000 \mathrm{~kg} / \mathrm{m}^{3}$, viscosity $\gamma_{80} \leq 30 \mathrm{cSt}$ and flash point in closed crucible $\geq 55{ }^{\circ} \mathrm{C}$ ) at introducing parallel flow in the solid heat carrier unit TSK of Oil Plant NPP must be $0.32-0.278=0.042$ or $4.2 \%$ GTF .

Table 3. Results of laboratory-scale retorting of oil shale in an externally heated retort

\begin{tabular}{|l|c|c|}
\hline \multirow{2}{*}{ Characteristics } & \multicolumn{2}{|c|}{ Flow of VGM in the air cooler-condenser } \\
\cline { 2 - 3 } & Counter-current flow & Parallel flow \\
\hline Oil yield, dry oil shale basis, \% & 13.16 & 15.26 \\
$\quad$ Middle-heavy oil & 2.53 & 1.51 \\
$\quad$ Light oil & & 984 \\
Density of shale oil, $\rho_{4}^{15}, \mathrm{~kg} / \mathrm{m}^{3}$ & 1083 & 786.1 \\
$\quad$ Middle-heavy oil & 807.4 & 22.7 \\
$\quad$ Light oil & 30.6 & \\
Viscosity at $50^{\circ} \mathrm{C}, \mathrm{cSt}$ & & \\
Middle-heavy oil & & \\
\hline
\end{tabular}


Variant 1

Counter-current contact of condensate (middle-heavy oil) and vapour-gas mixture in the cooler-condenser

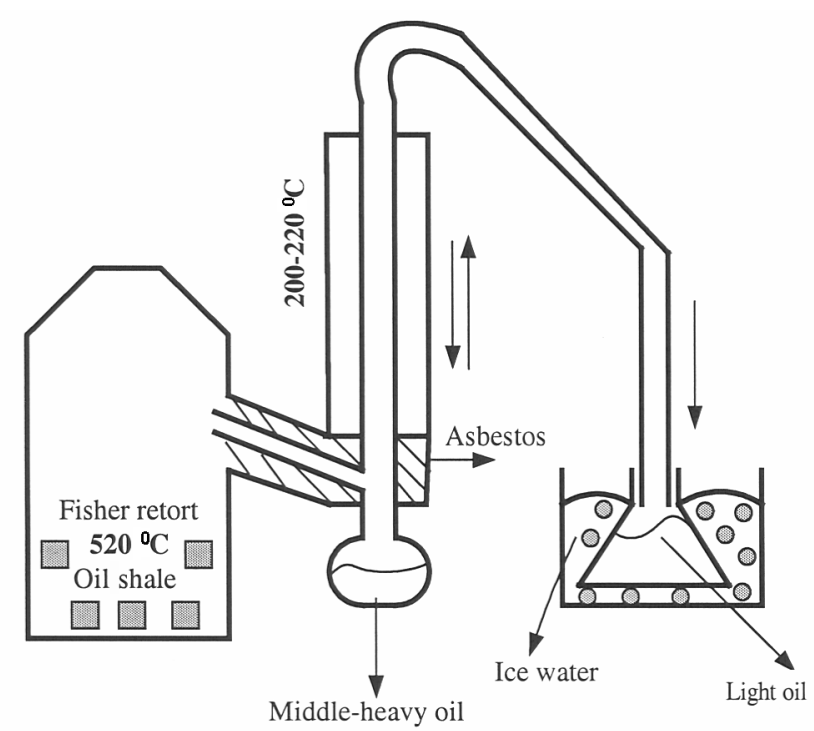

Variant 2

Parallel flow contact of condensate (middle-heavy oil) and vapour-gas mixture in the cooler-condenser

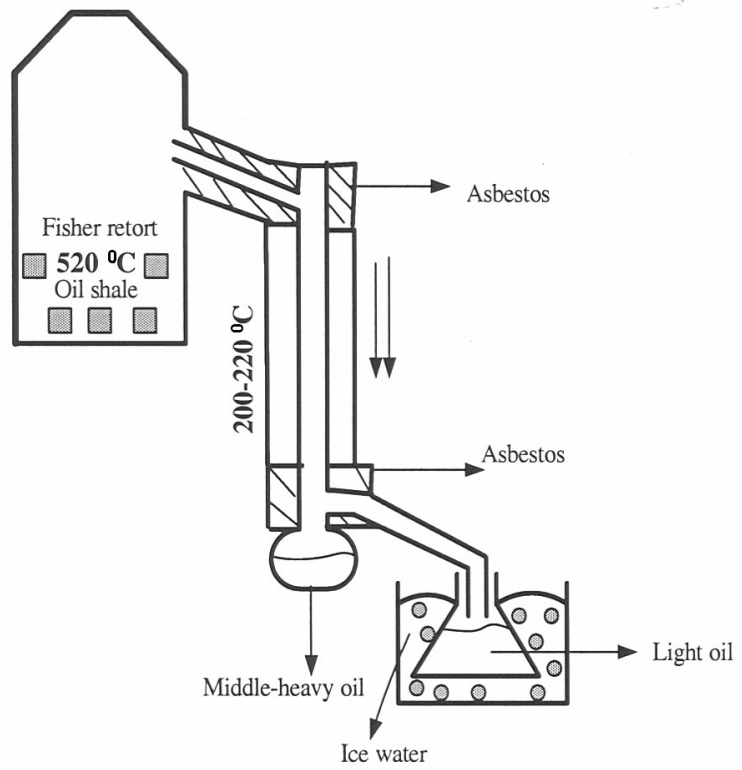

Fig. 3. Laboratory equipment for thermal processing of oil shale (counter-current and parallel flows in the cooler-condenser). 
At the present time density of the middle-heavy shale oil produced in Oil Plant $\rho_{\text {mho }}$ is $1045 \mathrm{~kg} / \mathrm{m}^{3}$, that of GTF $\rho_{\mathrm{GTF}}-904 \mathrm{~kg} / \mathrm{m}^{3}$. For obtaining the product shale oil with $\rho_{\mathrm{p}} 1000 \mathrm{~kg} / \mathrm{m}^{3}$, the required share of GTF for adding to middle-heavy shale oil makes:

$$
X_{\mathrm{GTF}}=\left(\rho_{\text {mho }}-\rho_{\mathrm{p}}\right) /\left(\rho_{\mathrm{mho}}-\rho_{\mathrm{GTF}}\right)=(1045-1000) /(1045-904)=0.32 .
$$

In this case we receive an oil constituting of $32 \%$ GTF and $68 \%$ middleheavy shale oil.

In the case of introducing parallel flow, the yield of GTF increases by $0.5 \mathrm{t} / \mathrm{h}$ on account of reduced temperature and avoiding the gripping of GTF by middle-heavy shale oil:

$$
\begin{aligned}
& \qquad G^{\text {ho }}=6704-500 \approx 6200 \mathrm{~kg} / \mathrm{h} . \\
& \rho_{\mathrm{p}}=\rho_{\mathrm{mho}} \cdot x_{\mathrm{mho}}+\rho_{\mathrm{ho}} \cdot x_{\mathrm{ho}}=1045 \cdot 0.504+1033 \cdot 0.496=1037, \\
& \text { where } \quad \begin{array}{l}
x_{\mathrm{mho}}=6200 / 12300=0.504, \\
x_{\mathrm{ho}}=0.496
\end{array}
\end{aligned}
$$

The share of GTF constitutes:

$$
X_{\mathrm{GTF}}=\left(\rho_{\mathrm{mho}}-\rho_{\mathrm{p}}\right) /\left(\rho_{\mathrm{mho}}-\rho_{\mathrm{GTF}}\right)=(1037-1000) /(1037-904)=0.278 \text {. }
$$

Basing on truthworthy calculations and laboratory-scale experiments, a project was worked out and put into practice at TSK Oil Plant NPP in 2006.

In the course of exploitation of parallel flow during may-june 2006 under established optimal pyrolysis conditions in the retorting section of Oil Plant, changes in density and viscosity of middle-heavy shale oil were proved. Industrial experiments gave the following average results (Table 4):

Additional calculations give

$$
\begin{aligned}
X_{\mathrm{GTF}}=\left(\rho_{\mathrm{mho}}-\rho_{\mathrm{p}}\right) /\left(\rho_{\mathrm{mho}}-\rho_{\mathrm{GTF}}\right) & =(1040-1000) /(1040-896)=0.278 . \\
0.32-0.278 & =0.042 \text { or } 4.2 \% \mathrm{GTF} .
\end{aligned}
$$

We drew the conclusion that the set purpose - decrease in density and viscosity of middle-heavy shale oil through converting the movement of VGM in the air-cooler-condenser resulting in essential reduction of the residence time of shale oil vapors in the high-temperature zone - was achieved.

Table 4. Comparative characeteristics of two shale oil fractions

\begin{tabular}{|l|c|c|}
\hline \multirow{2}{*}{ Characteristics } & \multicolumn{2}{|c|}{ Flow of VGM in the air cooler-condenser } \\
\cline { 2 - 3 } & Counter-current flow & Parallel flow \\
\hline Density of shale oil, $\rho_{4}^{15}, \mathrm{~kg} / \mathrm{m}^{3}$ & 1045 & 1040 \\
Middle-heavy oil & 904 & 896 \\
Light oil (GTO) & \\
\hline
\end{tabular}


It confirms once more the postulates concerning thermal processing of vapor-gaseous products of oil shale and shale oil:

The components of primary vapor-gaseous products are thermally labile and incline to further thermal transformation - mainly in the direction of bodying.

From this follows the fundamental rule without exceptions: acceleration of evacuation of vapor-gas products from high-temperature zone increases oil yield and decreases oil bodying.

\section{REFERENCES}

1. Oil Factory production. Eesti Energia, AS Narva Elektrijaamad (Estonian Energy, Narva Power Plants). Factory standard EE 10579981-NJ ST9:2005. Eesti Energia, 2005. 24 pp.

2. Estonian Patent of Narva Power Plant EE 04502 B1. Solid heat carrier plant for thermal processing of solid fuels, solid and also liquid industrial wastes // The Estonian Patent Gazette. 2005. No. 3. P. 31.

3. Stelmakh, G. P., Tyagunov, B. I., Chikul, V. I., Gudkin, M. Z., Senchugov, K. I. Energy process plant for fine-graine shale // Oil Shale. 1985. Vol. 2, No. 2. P. 189-196 [in Russian].

4. Kann, J., Elenurm, A., Rohtla, I., Golubev, A., Kaidalov, B. About thermal lowtemperature processing of oil shale by solid heat carrier method // Oil Shale. 2004. Vol. 21, No. 3. P. 195-203.

5. Kaidalov, A. N., Vereshchaka, S. A. Estimation of economic effect about inculcating the parallel flow in the cooler-condensers of heavy oil fraction. - Oil Plant of Narva PP, 2004.

6. Kaidalov, K. A. Low-temperature retorting of heavy petroleum wastes together with oil shale by solid heat carrier method. Master's dissertation (supervised by A. Kaidalov and J. Soone). - Tallinn University of Technology, 2004.

7. Gelperin, N. I. Fundamental Processes and Units of Chemical Engineering. Vol. 1. - Moscow: Khimiya, 1981. 384 pp. [in Russian].

Presented by J. Soone

Received January 20, 2007 